Article

\title{
Isothioureas, Ureas, and Their $N$-Methyl Amides from 2-Aminobenzothiazole and Chiral Amino Acids
}

\author{
Itzia I. Padilla-Martínez ${ }^{1}{ }^{\mathbb{D}}$, José Miguel González-Encarnación ${ }^{1}$, Efrén V. García-Báez ${ }^{1}$, \\ Alejandro Cruz ${ }^{1, *}$ and Ángel Andrés Ramos-Organillo ${ }^{2}$ D \\ 1 Instituto Politécnico Nacional-UPIBI, Laboratorio de Química Supramolecular y Nanociencias, Av. \\ Acueducto s/n, Barrio la Laguna Ticomán 07340, México City, Mexico; ipadillamar@ipn.mx (I.I.P.-M.); \\ jos3mi6uelglez@gmail.com (J.M.G.-E.); efren1003@yahoo.com.mx (E.V.G.-B.) \\ 2 Facultad de Ciencias Químicas, Universidad de Colima, Km 9 Carr. Colima-Coquimatlán, \\ Coquimatlán 28400, Colima, Mexico; aaramos@ucol.mx \\ * Correspondence: alcralmx@hotmail.com; Tel.: +52-555-729-6000 (ext. 56323)
}

Academic Editor: Sven Mangelinckx

Received: 15 August 2019; Accepted: 10 September 2019; Published: 18 September 2019

\begin{abstract}
In this investigation, the reaction of 2-dithiomethylcarboimidatebenzothiazole with a series of six chiral amino-acids was studied. The reaction proceeds through the isolable sodium salt of SMe-isothiourea carboxylates as intermediates, whose reaction with methyl iodide in stirring DMF as solvent affords SMe-isothiourea methyl esters. The presence of water in the reaction leads to the corresponding urea carboxylates as isolable intermediates, whose methyl esters were obtained. Finally, the urea $\mathrm{N}$-methyl amide derivatives were isolated when SMe-isothiourea or urea methyl esters were reacted with methylamine in the presence of water. The structures of synthesized compounds were established by ${ }^{1} \mathrm{H}$ and ${ }^{13} \mathrm{C}$ nuclear magnetic resonance and the structures of SMe-isothiourea methyl esters derived from $(l)$-glycine, $(l)$-alanine, $(l)$-phenylglycine, and (l)-leucine, by $\mathrm{X}$-ray diffraction analysis. This methodology allows to functionalize 2-aminobenzothiazole with SMe-isothiourea, urea, and methylamide groups derived from chiral amino acids to get benzothiazole derivatives containing coordination sites and hydrogen bonding groups. Further research on the biological activities of some of these derivatives is ongoing.
\end{abstract}

Keywords: 2-aminobenzothiazole; 2-dithiomethylcarboimidatebenzothiazole; $\alpha$-amino-acids; S-methylisothioureas; urea-carboxylate methyl esters and urea $\mathrm{N}$-methyl amides

\section{Introduction}

Benzothiazole is an aromatic bicyclic ring system that consists of a thiazole ring fused with a benzene ring. The benzothiazole moiety is small but a very interesting compound with wide biological activities. At the beginning of the 1970s, it was found that benzothiazole derivatives possessed pharmacological antiviral [1-3], antibacterial [3-6], antimicrobial [7-9], fungicidal [10,11], antiallergic [12-14], antidiabetic [15-17], antitumoral [18-21], anti-inflammatory [22,23] and anthelmintic [24-26] activities.

A continuous interest in this class of compounds follows nowadays and numerous efforts to synthesize new biologically active heterocyclic compounds derived from the benzothiazole moiety have been made in the last 50 years. Several of these derivatives were found to possess anticonvulsant [27-29] and antioxidant [30-32] activities. In this context, some results related to molecules containing benzothiazole nuclei in medicinal chemistry have been summarized elsewhere [33,34].

On the other hand, guanidines are an important class of compounds that are found widely throughout nature and as biologically active synthetic compounds, and several uses in organic chemistry are known [35-38]. For example, the natural amino acid arginine has a guanidine group as 
side chain, whilst cimetidine, a synthetic guanidine-derived compound, was the first drug used to treat peptic ulcers.

Typically, the reaction of amines with thioureas [39] or isothioureas [40-42] is the most commonly used method to obtain guanidines. Particularly, the isothiourea group has been bonded to a solid phase as precursor of guanidines [43]. In the last decade, it has been recognized that isothioureas can also serve as remarkably potent inhibitors for a range of enzymatic systems [44-46]. On the other hand, inhibition of nitric oxide synthase (NOS) has led to their use in the treatment of a range of life-threatening conditions, including septic shock, acute kidney failure, and rejection after transplantation surgery [47].

In this sense, we report a synthetic way to prepare symmetrical and nonsymmetrical guanidines 4 derived from 2-aminobenzothiazole 1 by the reaction of 2-dithiomethylcarboimidatebenzothiazole 2 with primary amines in refluxing ethanol [48]. The reaction proceeds through the formation of SMe-isothioureas 3, as intermediates, and the displacement of two MeSH molecules [49], Scheme 1.

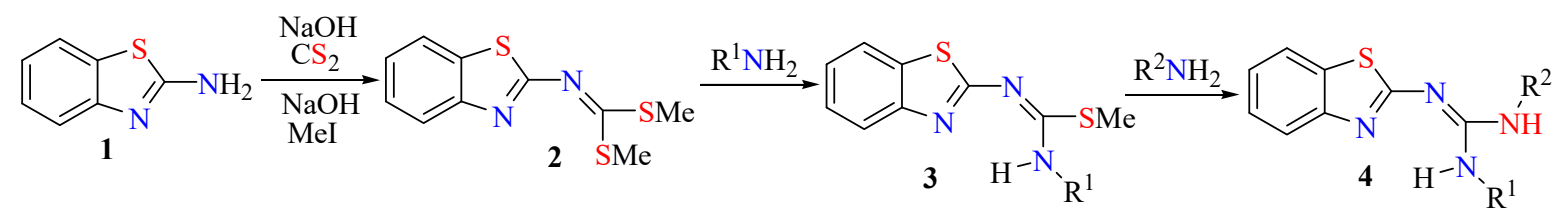

Scheme 1. Dithiomethylcarboimidatebenzothiazole 2, SMe-isothioureas 3 and guanidines 4 starting from 2-aminobenzothiazole 1.

In this contribution, we applied this methodology in the reaction of $\mathbf{2}$ with a series of chiral amino acids to form the corresponding SMe-isothiourea carboxylates 5 , which were further transformed into the corresponding isourea carboxylates 6, methyl ester derivatives 8-10 and $\mathbf{1 2}$, and isourea amides $\mathbf{1 1}$, and 13. This methodology allows the functionalization of 2-aminobenzothiazole to introduce groups such as isothioureas, isoureas ureas, amides, and guanidines derived from chiral amino acids. These functional groups give properties such as coordinating sites, hydrogen bonding interactions, and water solubility, among others, required for the interaction with biomolecules. The reactions were carried out without modification of the chiral center configuration and all compounds were optically pure isolated as shown in the analyzed X-ray structures of compounds $\mathbf{8 b , c}$ and $\mathbf{9 f}$.

\section{Results and Discussion}

\subsection{Reactions and Characterization}

Six amino acids Aa-f were tested: glycine $(\mathrm{R}=\mathrm{H}, \mathbf{a}),(l)$-alanine $(\mathrm{R}=\mathrm{Me}, \mathbf{b}),(l)$-phenylglycine $(\mathrm{R}=\mathrm{Ph}, \mathrm{c}),(l)$-phenylalanine $(\mathrm{R}=\mathrm{Bn}, \mathrm{d}),(l)$-valine $\left(\mathrm{R}={ }^{\mathrm{i}} \mathrm{Pr}, \mathbf{e}\right)$, and $(l)$-leucine $\left(\mathrm{R}={ }^{\mathrm{i}} \mathrm{Bu}, \mathrm{f}\right)$, represented as the zwitterions Ba-f. Each amino acid was transformed in situ into the corresponding sodium carboxylate $\mathbf{C a}-\mathbf{f}$ by reaction with one molar equivalent of sodium hydroxide in stirring ethanol for $2 \mathrm{~h}$ at room temperature, Scheme 2.

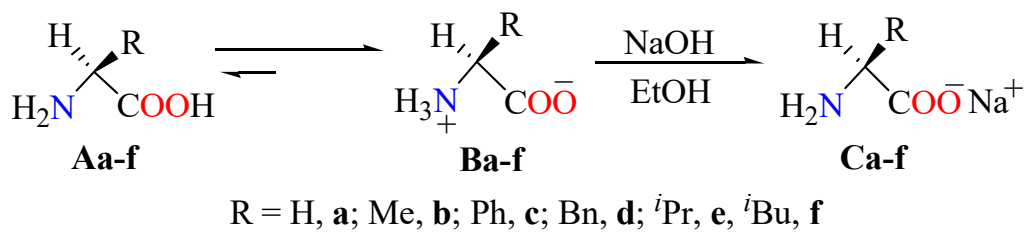

Scheme 2. Generation of sodium carboxylates $\mathbf{C}$ from neutral amino acids $\mathbf{A}$.

The reaction of one molar equivalent of 2-dithiomethylcarboimidatebenzothiazole 2 with the corresponding amino-acid carboxylates $\mathbf{C a}-\mathbf{f}$ at refluxing ethanol for eight hours was carried out. In these conditions, the reaction proceeds by nucleophilic attack of the amino group of the amino-carboxylates $\mathbf{C}$ to the carbonimidothioate group of compound 2 , with elimination of 
thiomethanol gas to afford the corresponding SMe-isothiourea-carboxylates $5 \mathbf{a}-\mathbf{f}$ in $40-86 \%$ yields. The ${ }^{1} \mathrm{H}$ NMR spectroscopic data of compounds $\mathbf{5 a - f}$ are listed in Table S3. A singlet for the SMe group is found in the 2.35-2.44 ppm range, whose integration area are in a 3:4 proportion in relation to the aromatic hydrogen atoms. The chemical shift of the NH group to high frequency (10.6-11.4 ppm) is explained due to a hydrogen bonding interaction with the nitrogen atom of the benzothiazole moiety, as depicted in Scheme 3. On the other hand, the ${ }^{13} \mathrm{C}$ NMR data, listed in Table S4, show characteristic signals from 13.9 to 14.1 and 169.7 to $171.6 \mathrm{ppm}$ ranges for the $\mathrm{SMe}$ and $\mathrm{OC}=\mathrm{O}$ groups, respectively.

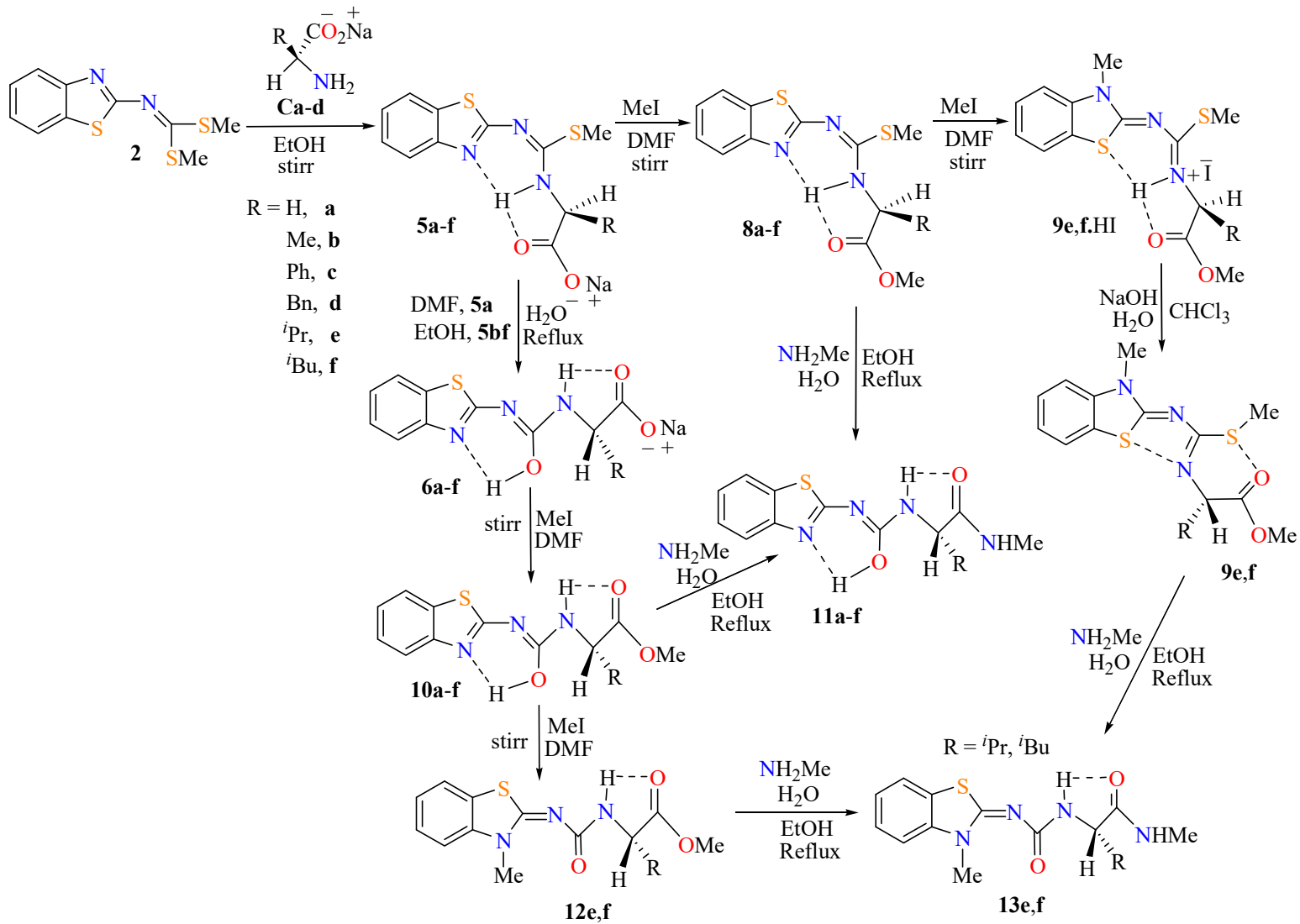

Scheme 3. Synthesis of SMe-isothiourea carboxylates $\mathbf{5 a}-\mathbf{f}$, isourea-carboxylates $\mathbf{6 a}-\mathbf{f}$, their corresponding methyl esters $\mathbf{8 a}-\mathbf{f}, \mathbf{9 e}, \mathbf{f}, \mathbf{1 0 a}-\mathbf{f}$, and $\mathbf{1 2 e}, \mathbf{f}$, isourea-amides 11a-f and urea-amides 13e,f derived from benzothiazole and amino acids.

In the case of the reaction of compound 2 with valine- $\left(\mathbf{C e}, \mathrm{R}={ }^{\mathrm{i}} \mathrm{Pr}\right)$ or leucine- $\left(\mathbf{C f}, \mathrm{R}={ }^{\mathrm{i}} \mathrm{Bu}\right)$ carboxylates, an insoluble yellowish solid appeared in the reaction mixture, which was identified as compound 7. The ${ }^{1} \mathrm{H}$ NMR spectrum shows two singlets at $2.6 \mathrm{ppm}(\mathrm{SMe})$ and $3.9(\mathrm{NMe})$ each in a 3:4 proportion with respect to the aromatic hydrogen atoms. In the ${ }^{13} \mathrm{C} N M R$ spectrum, the signals for $\mathrm{SMe}$, NMe, and the thiocarbonyl group at 18.6, 33.7, and 208.7 ppm, respectively, appeared. To explain these results, a sigmatropic rearrangement of compound 2 to form compound 7 in $15 \%$ yield is proposed, as depicted in Scheme 4, in agreement with ${ }^{1} \mathrm{H}$ and ${ }^{13} \mathrm{C}$ NMR data.

Isorea carboxylate compound $6 \mathrm{c}$ was isolated as byproduct in $20 \%$ yield, from the remaining mother liquors of 5c. No signal for the SMe group was present in the NMR spectra of compound $\mathbf{6 c}$, but two interchangeable protons with deuterium were observed at $11.8 \mathrm{ppm}$, corresponding to the isourea $\mathrm{OH}$, and at $8.3 \mathrm{ppm}$, attributed to the urea $\mathrm{NH} .{ }^{1} \mathrm{H}$ and ${ }^{13} \mathrm{C}$ NMR spectroscopic data of compound $6 \mathrm{c}$ are listed in Tables S5 and S6, respectively. The substitution of the remaining SMe group in compound $5 c$ by one molecule of water afforded compound $6 c$ as one of the two possible tautomers, Table S5.

To improve the yields of the sodium salt of SMe-isotiourea carboxylates $\mathbf{5} \mathbf{b}-\mathbf{f}$, the reactions were carried out using anhydrous ethanol and stirring for 4 days at room temperature to avoid 
hydrolysis. In these conditions, the reaction proceeds more slowly to afford the corresponding SMe-isothiourea-carboxylates $\mathbf{5 b}-\mathbf{f}$ in $62-95 \%$ yields. On the other hand, the complete hydrolysis of SMe-isotiourea carboxylates $\mathbf{5 b} \mathbf{b} \mathbf{f}$ in a refluxing mixture of ethanol:water 1:1 was carried out. In these conditions, the second thiomethanol gas molecule was eliminated to afford the corresponding isourea carboxylates $\mathbf{6 b}-\mathbf{e}$ as the only products in $65-75 \%$ yields. The hydrolysis of compound 5 a required more drastic conditions such as refluxing in $\mathrm{DMF} / \mathrm{H}_{2} \mathrm{O}$ mixtures to obtain $6 \mathrm{a}$ in $40 \%$ yield.

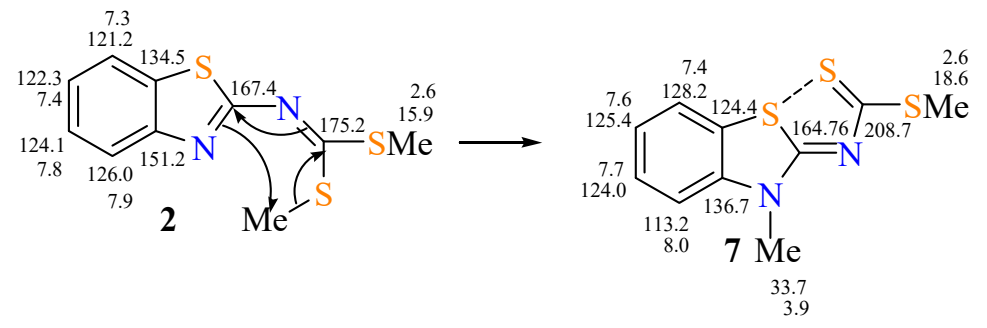

Scheme 4. Sygmatropic rearrangement of compound 2. The numbers on the atoms are the ${ }^{1} \mathrm{H}$ and ${ }^{13} \mathrm{C}$ chemical shifts in $\mathrm{CDCl}_{3}$.

The corresponding SMe-isothiourea carboxylate methyl esters $\mathbf{8 a - d}$ were obtained in 56-83\% yields after the methylation of carboxylates $\mathbf{5 a - d}$ with one molar equivalent of methyl iodide in DMF as solvent, whose ${ }^{1} \mathrm{H}$ and ${ }^{13} \mathrm{C}$ NMR chemical shifts are listed in Tables S7 and S8, respectively. In general, their spectra are very similar compared to the corresponding carboxylates $\mathbf{5 a}-\mathbf{d}$, except for the OMe group signals which are in the 3.75-3.83 and 45-53 ppm ranges in ${ }^{1} \mathrm{H}$ and ${ }^{13} \mathrm{C} \mathrm{NMR}$ spectra, respectively. The ${ }^{13} \mathrm{C}$ NMR data of esters $8 \mathbf{c}, \mathbf{d}$ in $\mathrm{CDCl}_{3}$ show broad signals for $\mathrm{C} 2, \mathrm{C}$, and $\mathrm{C} 11$, suggesting that the usually fast proton exchange between N3 and N12 through tautomeric equilibria becomes slower because of the steric effects of the phenyl and benzyl moieties from the amino-acid residue.

The use of one equivalent of iodomethane in the reaction of SMe-isothiourea-carboxylates 5e or $\mathbf{5 f}$, afforded the respective methyl esters $\mathbf{8 e}$ ( $49 \%$ yield) or $\mathbf{8 f}$ ( $51 \%$ yield) in mixture with the corresponding N3-Me methyl esters $\mathbf{9 e}(8 \%$ yield) or $\mathbf{9 f}$ ( $25 \%$ yield) and their hydroiodides $\mathbf{9 e} \cdot \mathrm{HI}$ or $\mathbf{9 f} \cdot \mathrm{HI}$. Compound $\mathbf{5 f}$ was reacted with two molar equivalents of $\mathrm{CH}_{3} \mathrm{I}$; however, compounds $\mathbf{8 f}$ and $\mathbf{9 f} \cdot \mathrm{HI}$ remained. This last compound precipitated from the reaction mixture and was separated for further analysis. ${ }^{1} \mathrm{H}$ and ${ }^{13} \mathrm{C}$ chemical shifts comparison between compounds $\mathbf{9 e}, \mathbf{9 f} \cdot \mathrm{HI}$, and $\mathbf{9 f}$ is depicted in Figure 1 . The characteristic ${ }^{1} \mathrm{H}\left({ }^{13} \mathrm{C}\right) \mathrm{NMR}$ signals of $9 \mathrm{f} \cdot \mathrm{HI}$, are the SMe group at $\delta 3.1(18.3), \mathrm{N}-\mathrm{Me}$ at $3.8(56.5)$, and $\mathrm{N}-\mathrm{H}$ at $9.1 \mathrm{ppm}$. The high frequency shift of the NH suggests a hydrogen bonding interaction with the sulfur atom and/or with the carbonyl oxygen atom, Figure 1. The nitrogen atom of the N-Me group on the benzothiazole produces an electronic effect on $\mathrm{C} 4$ of the aromatic ring, shifting it to low frequencies: $114.1 \mathrm{ppm}$ for $\mathbf{9 f} \cdot \mathrm{HI}$ and $\approx 110 \mathrm{ppm}$ for $\mathbf{9 e}$ and $\mathbf{9 f}$.
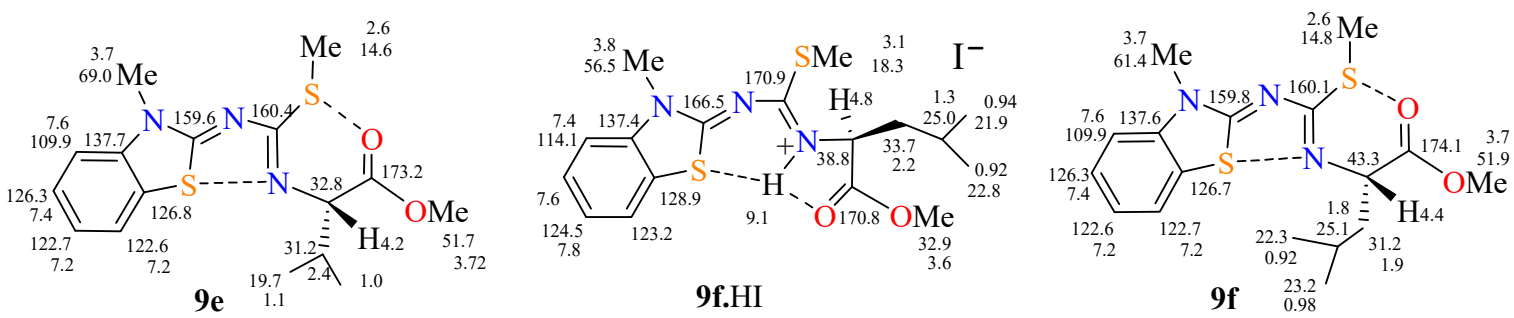

Figure 1. ${ }^{1} \mathrm{H}$ and ${ }^{13} \mathrm{C} \mathrm{NMR}$ data in $\mathrm{CDCl}_{3}$ of compounds $9 \mathbf{e}, \mathbf{9 f}$, and $9 \mathrm{f} \mathrm{HI}$.

The isourea-carboxylates $\mathbf{6 a}-\mathbf{d}$ can also be methylated to afford the isourea methyl esters $\mathbf{1 0 a}-\mathbf{d}$ in $30-90 \%$ yields, Scheme 3. However, the methylation reaction of the sodium salts of isourea-carboxylates 6e or $6 f$ afforded the corresponding methyl esters $10 \mathbf{e}(66 \%)$ or $10 f(54 \%)$ in mixture with their N-Me esters $12 \mathbf{e}(24 \%)$ or $\mathbf{1 2} \mathbf{f}(21 \%) .{ }^{1} \mathrm{H}$ and ${ }^{13} \mathrm{C}$ NMR data of compounds $\mathbf{1 0 a}-\mathbf{f}$ are listed in Tables S9 and S10, respectively, and those of urea-methyl esters $\mathbf{1 2 e}$ and $\mathbf{1 2 f}$ are depicted in Figure 2. 

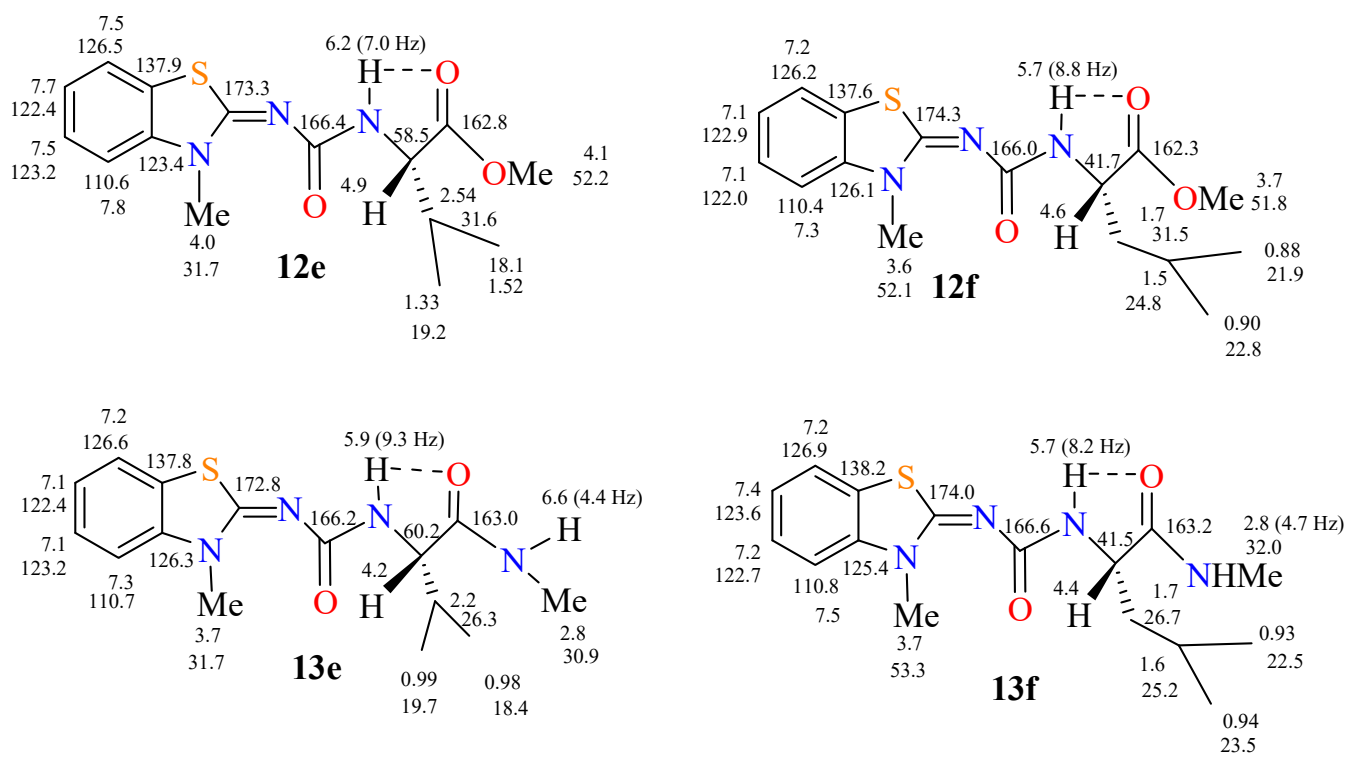

Figure 2. ${ }^{1} \mathrm{H}$ and ${ }^{13} \mathrm{C}$ NMR data in $\mathrm{CDCl}_{3}$ of urea carboxylate methyl esters $\mathbf{1 2 e}, \mathbf{1 2 f}$, and their corresponding urea NMe amides 13e, 13f.

Isourea carboxylate methyl esters $\mathbf{1 0 a}-\mathbf{f}$ or $\mathbf{1 2 e}, \mathbf{f}$ were reacted with methylamine to afford their corresponding isourea amides 11a-f or urea-amides 13e,f in $60-97 \%$ yield or $20 \%$ and $46 \%$ yields, respectively. The ${ }^{1} \mathrm{H}$ and ${ }^{13} \mathrm{C}$ NMR spectra of compounds 11a-f are listed in Tables S11 and S12 and those of compounds 13e,f are depicted in Figure 2. The ${ }^{1} \mathrm{H}$ NMR spectrum of isourea-amides 11a- $\mathbf{f}$ show three deuterium labile hydrogen atoms in the 8.4-10.9, 7.0-10.6, and 7.1-8.1 ppm ranges, as well as the characteristic doublet in 2.5-3.0 ppm range for the NHMe group. The C4 NMR frequencies were found at approximately $110 \mathrm{ppm}$ in both NMe esters $\mathbf{1 2 e}, \mathbf{f}$ and their amides $\mathbf{1 3 e}, \mathbf{f}$. The $10 \mathrm{ppm}$ shift to low frequencies compared with their NH analogues $10 a-f$ and 11a-f was due to the electronic effect of the NMe group on C4. In compounds $\mathbf{1 3 e}$ and $\mathbf{1 3 f}$, the urea NH appears as a doublet at 5.9 $\left({ }^{3} \mathrm{~J}=9.3 \mathrm{~Hz}\right)$ and $5.7 \mathrm{ppm}\left({ }^{3} \mathrm{~J}=8.2 \mathrm{~Hz}\right)$; and the amide $\mathrm{NH}$ appears at lower frequency as a quartet at $6.6\left({ }^{3} \mathrm{~J}=4.4 \mathrm{~Hz}\right)$ and $6.4 \mathrm{ppm}\left({ }^{3} \mathrm{~J}=4.7 \mathrm{~Hz}\right)$, respectively.

Isothiourea carboxylate methyl esters 8a-f contain both SMe and OMe groups, which are susceptible to substitution with nucleophiles such as methylamine. The reaction of compounds $8 \mathbf{a}$ with one molar equivalent of methylamine produces a complex mixture of several methylated compounds. However, in the presence of an excess of methylamine, the isourea-amide compound 11a precipitated as a white solid. In these conditions, the SMe group was substituted because of the formation of $\mathrm{MeNH}_{3} \mathrm{OH}$ in aqueous medium. The last procedure was also used with the urea methyl esters $\mathbf{8 b} \mathbf{b} \mathbf{f}$ and $\mathbf{9 e}, \mathbf{f}$ to obtain compounds $\mathbf{1 1} \mathbf{b}-\mathbf{f}$ and $\mathbf{1 3 e}, \mathbf{f}$ in $45-60 \%$ yields.

\subsection{Molecular Structure of Compounds $\mathbf{8 a - c}$ and $\mathbf{9 f}$}

The SMe-isothiourea methyl esters (S)-8a-c and (S)-9f were purified by crystallization from ethanol and suitable crystals for X-ray diffraction analysis were isolated. The molecular structures of compounds 8a and 8c, displayed in Figures 3 and 4, show that the N12H is engaged in intramolecular three-centered hydrogen bonding interaction with the benzothiazole nitrogen and carbonyl oxygen

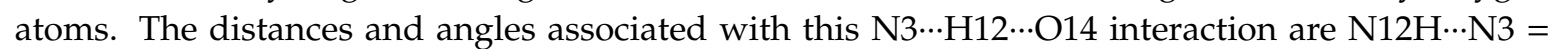
$2.01 \AA, 132^{\circ}$ (8a) and $2.03 \AA, 132^{\circ}(\mathbf{8 c}) ; \mathrm{N} 12 \mathrm{H} \cdots \mathrm{O} 14=2.31 \AA, 107^{\circ}(\mathbf{8 a})$ and $2.21 \AA, 111^{\circ}(\mathbf{8 c})$, forming the corresponding adjacent six (S6) and five (S5)-membered rings. This hydrogen bonding interaction fixes the stereochemistry of the imine $\mathrm{N} 10-\mathrm{C} 11$ bond and only the $(E)$ isomer of $8 \mathbf{a}$ and $\mathbf{8 c}$ was produced. In addition, the lateral side chain is almost in the same plane of the benzothiazole, including the carbon atoms of both $\mathrm{OMe}$ and $\mathrm{SMe}$ groups. In general, the SMe group is the most deviated from the mean plane $\left[\mathrm{N}(10)-\mathrm{C}(11)-\mathrm{S}(23)-\mathrm{C}(24)-6.18(1)^{\circ}\right]$ compared with the OMe group $[\mathrm{O}(14)-\mathrm{C}(14)-\mathrm{O}(15)-\mathrm{C}(16)$ 
$\left.0.25(1)^{\circ}\right]$. In the structure of compound $(S)-8 \mathbf{b}$, displayed in Figure 5, only the intramolecular hydrogen

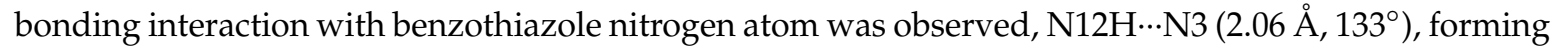
the corresponding six membered ring (S6). Therefore, the isothiourea group is in the same plane of the benzothiazole, including the chiral carbon atom, $\mathrm{N}(10)-\mathrm{C}(11)-\mathrm{N}(12)-\mathrm{C}(13)-178.71(1)^{\circ}$ and $\mathrm{S}(23)-\mathrm{C}(11)-\mathrm{N}(12)-\mathrm{C}(13) 0.16(1)^{\circ}$. In this case, the carbon atom of the SMe group is deviated from the benzothiazole ring planes, $\mathrm{N}(10)-\mathrm{C}(11)-\mathrm{S}(23)-\mathrm{C}(24)=5.19(1)^{\circ}$ and the carboxylate group is almost perpendicular to the plane of the molecule $C(14)-C(13)-N(12)-C(11)=-85.82(1)$.

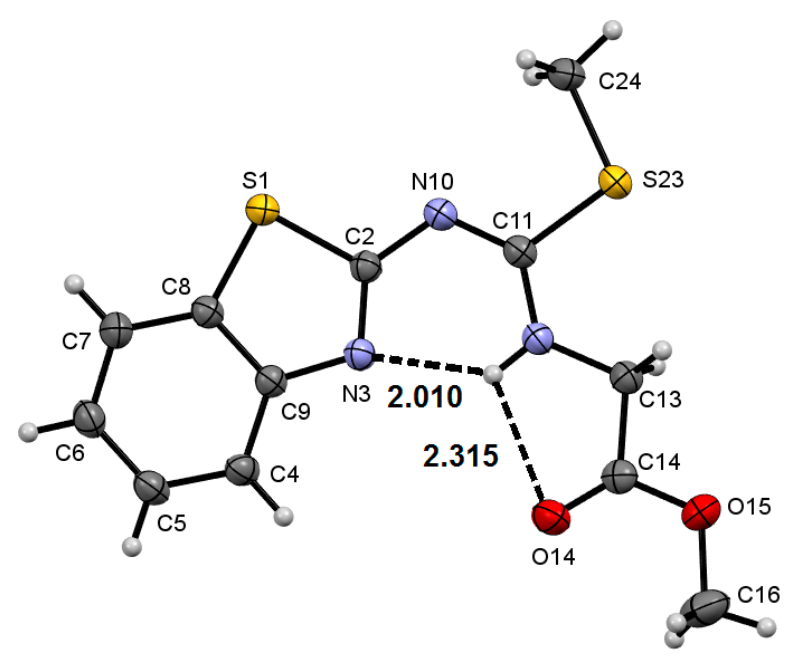

Figure 3. X-ray diffraction structure of compound 8a. Bond lengths (Å): $\mathrm{S}(1)-\mathrm{C}(2)$ 1.7624(1), $\mathrm{S}(1)-\mathrm{C}(8)$ 1.7342(1), S(23)-C(11) 1.7599(1), S(23)-C(24) 1.7927(1), N(3)-C(2) 1.3115(1), N(3)-C(9) 1.3855(1), N(10)-C(2) 1.3621(1), N(10)-C(11) 1.3104(1), N(12)-C(11) 1.3308(1), N(12)-C(13) 1.4402(1), $\mathrm{O}(14)-\mathrm{C}(14)$ 1.1936(1), O(15)-C(14) 1.3291(1), O(15)-C(16) 1.4530(1). Bond angles (Deg.): C(2)-S(1)-C(8) 89.25(1), C(11)-S(23)-C(24) 1102.17(1).Torsion angles (Deg.): $\mathrm{S}(23)-\mathrm{C}(11)-\mathrm{N}(10)-\mathrm{C}(2)$ 179.34(1), $\mathrm{N}(10)-\mathrm{C}(11)-\mathrm{S}(23)-\mathrm{C}(24)-6.18(1), \mathrm{N}(10)-\mathrm{C}(11)-\mathrm{N}(12)-\mathrm{C}(13)$ 178.17(1), N(12)-C(13)-C(14)-O(14) 2.25(1), $\mathrm{N}(12)-\mathrm{C}(13)-\mathrm{C}(14)-\mathrm{O}(15)-177.67(1), \mathrm{O}(14)-\mathrm{C}(14)-\mathrm{O}(15)-\mathrm{C}(16) 0.25(1)$.

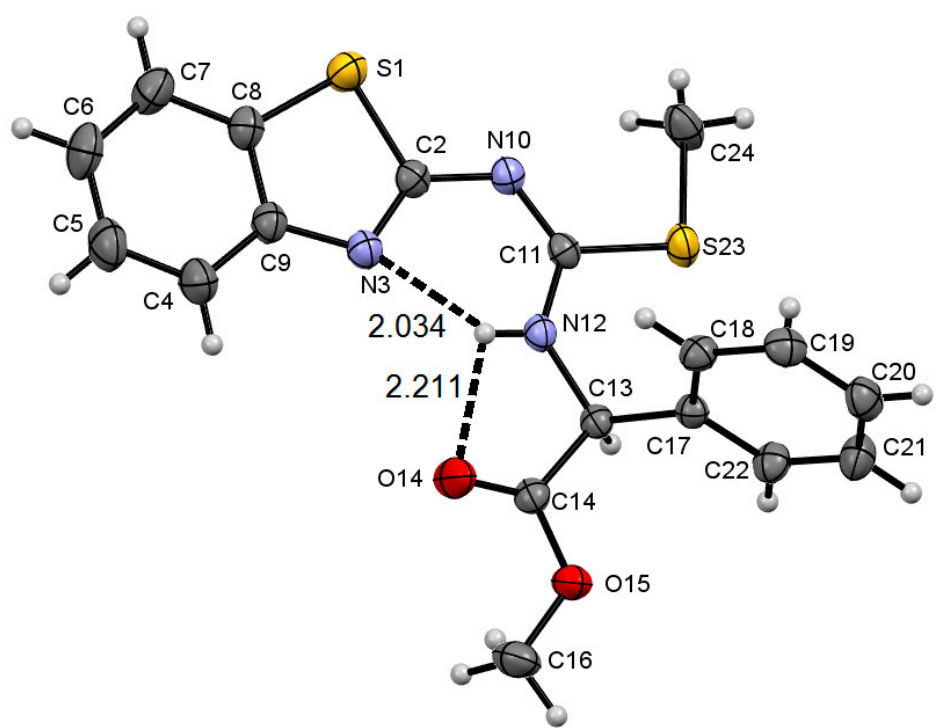

Figure 4. X-ray diffraction structure of compound 8c. Bond length $(\AA)$ : $S(1)-C(2)$ 1.753(2), $\mathrm{N}(3)-\mathrm{C}(2)$ 1.301(3), N(10)-C(2) 1.372(3), N(10)-C(11) 1.306(3), N(12)-C(11) 1.338(3), N(12)-C(13) 1.452(3), $\mathrm{S}(23)-\mathrm{C}(11)$ 1.770(2). Bond angles (Deg.): $\mathrm{S}(1)-\mathrm{C}(2)-\mathrm{N}(10)$ 115.55(16), N(3)-C(2)-N(10) 129.2 (2), $\mathrm{C}(2)-\mathrm{N}(10)-\mathrm{C}(11)$ 120.36(17), $\mathrm{N}(10)-\mathrm{C}(11)-\mathrm{N}(12)$ 126.08(18). Torsion angles (Deg.): $\mathrm{N}(3)-\mathrm{C}(2)-\mathrm{N}(10)-\mathrm{C}(11)-1.25, \mathrm{C}(24)-\mathrm{S}(23)-\mathrm{C}(11)-\mathrm{N}(10)$ 1.41(19), $\mathrm{C}(24)-\mathrm{S}(23)-\mathrm{C}(11)-\mathrm{N}(12)-179.90(17)$, $\mathrm{N}(12)-\mathrm{C}(13)-\mathrm{C}(14)-\mathrm{O}(14) 6.2(3), \mathrm{C}(16)-\mathrm{O}(15)-\mathrm{C}(14)-\mathrm{O}(14)-0.1(4)$. 


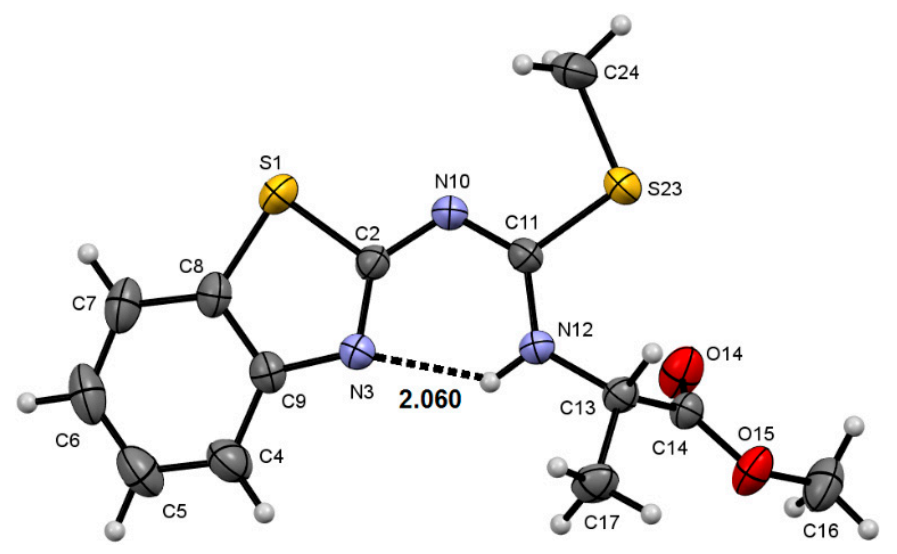

Figure 5. X-ray diffraction structure of compound 8b. Bond Lengths $(\AA)$ : $S(1)-C(2) 1.7618(1)$, $\mathrm{S}(1)-\mathrm{C}(8)$ 1.7300(1), S(23)-C(11) 1.7667(1), S(23)-C(24) 1.7919(1), O(14)-C(14) 1.1870(1), O(15)-C(14) 1.3134(1), $\mathrm{O}(15)-\mathrm{C}(16)$ 1.4522(1), N(3)-C(2) 1.2954(1), N(3)-C(9) 1.3912(1), N(10)-C(2) 1.3592(1), $\mathrm{N}(10)-\mathrm{C}(11)$ 1.3043(1), $\mathrm{N}(12)-\mathrm{C}(11)$ 1.3295(1), N(12)-C(13) 1.4527(1). Bond Angles (Deg.): $\mathrm{C}(2)-\mathrm{S}(1)-\mathrm{C}(8)$ 89.62(1), C(11)-S(23)-C(24) 101.25(1). Torsion angles (Deg.): N(3)-C(2)-S(1)-C(8) $-0.35(1), \mathrm{N}(10)-\mathrm{C}(2)-\mathrm{S}(1)-\mathrm{C}(8) 179.59(1), \mathrm{S}(1)-\mathrm{C}(2)-\mathrm{N}(3)-\mathrm{C}(9)$ 0.18(1), N(10)-C(2)-N(3)-C(9) - 179.74(1), $\mathrm{S}(1)-\mathrm{C}(2)-\mathrm{N}(10)-\mathrm{C}(11)-177.17(1), \mathrm{N}(3)-\mathrm{C}(2)-\mathrm{N}(10)-\mathrm{C}(11)$ 2.75(1), N(10)-C(11)-S(23)-C(24) 5.19(1), $\mathrm{N}(12)-\mathrm{C}(11)-\mathrm{S}(23)-\mathrm{C}(24)-173.79(1), \mathrm{S}(23)-\mathrm{C}(11)-\mathrm{N}(10)-\mathrm{C}(2)$ 179.27(1), N(12)-C(11)-N(10)-C(2) -1.88(1), $\mathrm{S}(23)-\mathrm{C}(11)-\mathrm{N}(12)-\mathrm{C}(13) \quad 0.16(1), \quad \mathrm{N}(10)-\mathrm{C}(11)-\mathrm{N}(12)-\mathrm{C}(13)-178.71(1), \quad \mathrm{C}(14)-\mathrm{C}(13)-\mathrm{N}(12)-\mathrm{C}(11)$ $-85.82(1), \mathrm{C}(17)-\mathrm{C}(13)-\mathrm{N}(12)-\mathrm{C}(11)$ 147.32(1), C(17)-C(13)-C(14)-O(14) 140.21(1).

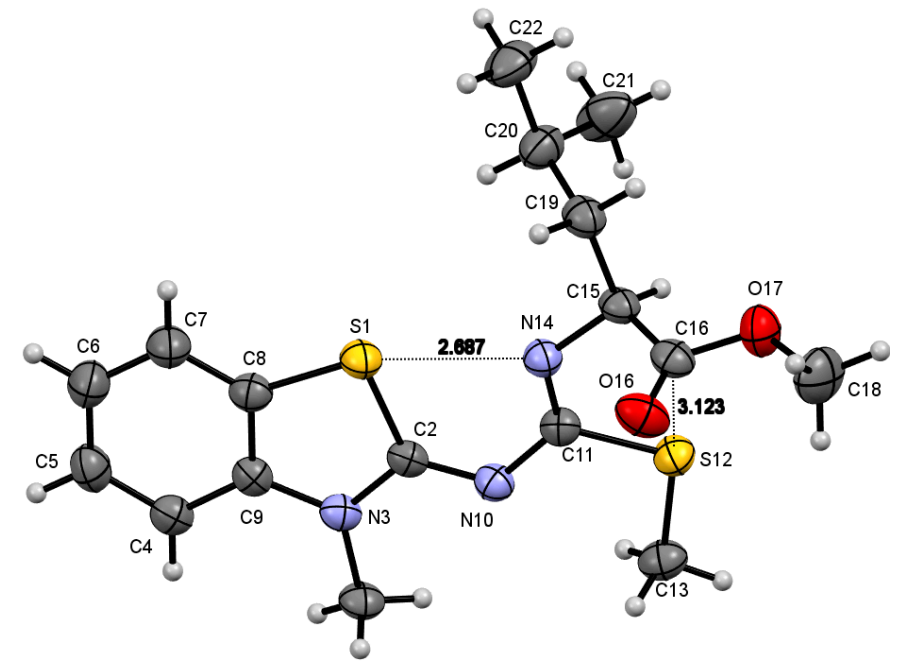

Figure 6. X-ray diffraction structure of compound 9f. Bond Lengths ( $)$ ). S1-C2 1.757(5), S1-C8 1.748(5), S12-C11 1.766(5), S12-C13 1.790(5), O16-C16 1.200(7), O17-C16 1.336(6), O17-C18 1.457(8), N3-C2 1.360(5), N3-C9 1.388(6), N3-C23 1.463(6), N10-C2 1.309(6), N10-C11 1.369(5), N14-C11 1.283(6), N14-C15 1.461(6), C4-C5 1.374(8). Torsion angles (Deg.): N3-C2-S1-C8 -2.4(4), N10-C2-S1-C8 175.6(5), S1-C2-N3-C9 2.3(5), S1-C2-N3-C23 -178.2(4), N10-C2-N3-C9 -175.8(4), N10-C2-N3-C23 3.6(7), S1-C2-N10-C11 2.1(7), N3-C2-N10-C11 179.9(4), N10-C11-S12-C13 -5.6(4), N14-C11-S12-C13 175.1(4), S12-C11-N10-C2 -169.8(4), N14-C11-N10-C2 9.6(7), S12-C11-N14-C15 -2.3(6), N10-C11-N14-C15 178.5(4), C16-C15-N14-C11 -70.1(5), C19-C15-N14-C11 169.6(4), N14-C15-C19-C20-66.1(6).

The structure of compound 9f is displayed in Figure 6. Two intramolecular noncovalent bonding interactions were observed, one of them is that of N14 with benzothiazole sulfur atom, S...N14 $(2.687 \AA)$, the other of $S 12$ with carbonyl carbon atom $S 12 \cdots C 16(3.123 \AA$ ), forming in both cases a five (S5)-membered ring. The first interaction causes both exocyclic nitrogen atoms to be almost in the 
same plane of the benzothiazole rings, including the chiral carbon and methylene carbon atoms of the isobutyl group. The SMe group is approximately $10^{\circ}$ deviated from the mean plane, S12-C11-N10-C2 $-169.8(4)$ compared with a small deviation of N10 [N10-C2-N3-C23 -3.6(7) ${ }^{\circ}$ and C11 [S1-C2-N10-C11 2.1(7) ${ }^{\circ}$.The second interaction maintain the $\mathrm{C}=\mathrm{O}$ and the isopropyl groups to be opposite each other deviated from the mean plane C16-C15-N14-C11 -70.1(5) and N14-C15-C19-C20 -66.1(6), respectively. Intermediate bond lengths values between single and double character for C2-N3 [1.330(5) $\AA$ ], C2-N10

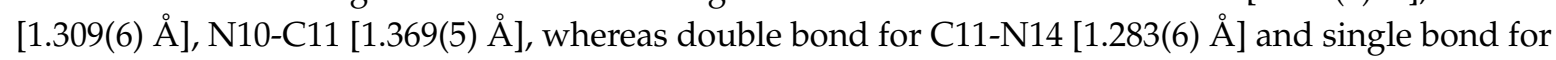
N14-C15 [1.461(6) ̊] were observed.

\section{Materials and Methods}

Melting points were measured on an IA 9100 apparatus (Electrothermal, Staffordshire, UK) and are uncorrected. IR spectra were recorded using a 3100 FT-IR Excalibur Series spectrophotometer (Varian, Randolph, MA, USA) equipped with an ATR system. Mass spectra were obtained in a 3900-GC/MS system (Varian, Palo Alto, CA, USA) with an electron ionization mode. Elemental analyses (EA) were performed on a 2400 elemental analyzer (Perkin-Elmer, Waltham, MA, USA). ${ }^{1} \mathrm{H}$ - and ${ }^{13} \mathrm{C}-\mathrm{NMR}$ spectra were recorded on a Varian Mercury $300\left({ }^{1} \mathrm{H}, 300.08 ;{ }^{13} \mathrm{C}, 75.46 \mathrm{MHz}\right)$ instrument in DMSO- $\mathrm{d}_{6}$ solutions for compounds $5 \mathrm{a}-\mathrm{f}$ and $6 \mathrm{a}-\mathrm{f}$, and $\mathrm{CDCl}_{3}$ in solutions for compounds $\mathbf{8} \mathbf{a}-\mathbf{f}, \mathbf{9 a}-\mathbf{f}, \mathbf{1 0 a}-\mathbf{f}, \mathbf{1 1 a}-\mathbf{f}, \mathbf{1 2 e}, \mathbf{f}$, and $\mathbf{1 3 e}, \mathbf{f} ; \mathrm{SiMe}_{4}$ was used as the internal reference. Chemical shifts are in ppm and ${ }^{n} J(\mathrm{H}-\mathrm{H})$ in hertz.

Crystals suitable for $\mathrm{X}$-ray analysis of $\mathbf{8 a}, \mathbf{8 b}, \mathbf{8 c}$, and $\mathbf{9 f}$ were obtained after solvent evaporation from saturated ethanol solutions. Single-crystal X-ray diffraction data were recorded on a D8 Quest CMOS (Bruker, Karlsruhe, Germany) or Nonius Kappa (Rotterdam, the Netherlands) area detector diffractometers with Mo $\mathrm{K} \alpha$ radiation, $\lambda=0.71073 \AA$. A table listing the crystallographic data is provided as Supplementary Material in Table S2. The structures were solved by direct methods using SHELXS97 [50] program of WinGX package [51]. The final refinement was performed by full-matrix least-squares methods on F2 with SHELXL97 [50] program. $\mathrm{H}$ atoms on C were geometrically positioned and treated as riding atoms, with $\mathrm{C}-\mathrm{H}=0.93-0.98 \AA$, and with $\mathrm{Uiso}(\mathrm{H})=1.2 \mathrm{Ueq}(\mathrm{C})$. The program Mercury was used for visualization, molecular graphics, and analysis of crystal structures [52]. The software used to prepare material for publication was PLATON [53]. Crystallographic data for the structures in this paper have been deposited with the Cambridge Crystallographic Data Centre as supplementary publication CCDC numbers 1949131 (8a), 1949129 (8b), 1413575 (8c) and 1949130 (9f). Copies of the data can be obtained free of charge on application to CCDC, 12 Union Road, Cambridge CB2 1EZ, UK (Fax: +44-01-223-336-033 or E-Mail: deposit@ccdc.cam.ac.uk).

\subsection{Experimental Section}

2-Aminobenzothiazole 1, $\mathrm{CS}_{2}$, iodomethane, glycine, $(l)$-alanine, (l)-phenyl-glycine, (ll)-phenylalanine, (l)-valine, (l)-leucine, DMF, ethyl alcohol and $\mathrm{NaOH}$ were commercial products, which were used as received. Yields, physical appearances, melting points, IR frequencies, and elemental analysis of compound $\mathbf{5 a}-\mathbf{f}$ and $\mathbf{8} \mathbf{a}-\mathbf{f}$ are listed in Table S1.

\subsection{General Method for Isothiourea Carboxylates 5a-f}

Amino acid (3.94 mmol), NaOH (3.94 mmol), and $15 \mathrm{~mL}$ of ethanol were added into a $100 \mathrm{~mL}$ round flask and the mixture was stirred for $2 \mathrm{~h}$ at room temperature. Then, compound 2 (1.0 g, $3.94 \mathrm{mmol}$ ) was added and the mixture was stirred for additional $96 \mathrm{~h}$ at room temperature.

\subsubsection{Sodium (E)-(3-Benzothiazol-2-Yl-2-Methyl-Isothioureido)-Acetate 5a}

As a general method, starting from $0.295 \mathrm{~g}$ of glycine, compound $5 \mathbf{a}$ precipitated from the reaction mixture, ethanol was eliminated, the resulting mixture was cooled to room temperature and $10 \mathrm{~mL}$ of acetone were added, the resulting suspension was filtered and washed with cold acetone, obtaining 5 a. $3 \mathrm{H}_{2} \mathrm{O}$ as a cream color powder $(1.14 \mathrm{~g}, 82 \%) ; \mathrm{mp}=220{ }^{\circ} \mathrm{C}(\mathrm{dc})$. 


\subsubsection{Sodium $(S, E)-(+)-2-(3-B e n z o t h i a z o l-2-Y 1-2-M e t h y l-I s o t h i o u r e i d o)-P r o p i o n a t e ~ 5 b$}

As a general method, starting from $0.35 \mathrm{~g}$ of $l$-alanine, ethanol was evaporated from the homogeneous reaction mixture, the resulting gummy product was dissolved in $10 \mathrm{~mL}$ of acetone and filtered, acetone was eliminated and a transparent yellowish ionic liquid compound $5 \mathrm{~b} .2 \mathrm{H}_{2} \mathrm{O}$ was obtained (1.08 g, 78\%), which resulted to be soluble in chloroform.

\subsubsection{Sodium $(R, E)-(+)-2-(3-B e n z o t h i a z o l-2-Y 1-2-M e t h y l-I s o t h i o u r e i d o)-P h e n y l-A c e t a t e ~ 5 c$}

As a general method, starting from $0.594 \mathrm{~g}$ of $l$-phenylglycine, ethanol was eliminated from the reaction mixture and then suspended in acetone $(10 \mathrm{~mL})$. The suspension was filtered and the remaining solid washed with cold acetone and dried to obtain a white powder $(1.29 \mathrm{~g}, 86 \%)$.

\subsubsection{Sodium (S,E)-(-)-2-(3-Benzothiazol-2-Y1-2-Methyl-Isothioureido)-3-Phenyl-Propionate 5d}

As a general method, starting from $0.650 \mathrm{~g}$ of $l$-phenylalanine, from the same procedure as $5 \mathbf{b}$, compound $\mathbf{5 d}$ was obtained as brownish liquid (1.26 $\mathrm{g}, 81 \%)$.

\subsubsection{Sodium (S,E)-(-)-2-(3-Benzothiazol-2-Y1-2-Methyl-Isothioureido)-3-Methyl-Butanonate 5e}

As a general method, starting from $0.673 \mathrm{~g}$ of $l$-valine, from the same procedure as $5 \mathbf{b}$, compound 5e was obtained as clear liquid $(1.09 \mathrm{~g}, 80 \%)$.

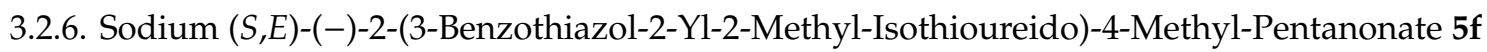

As a general method, starting from $0.516 \mathrm{~g}$ of $l$-leucine, from the same procedure as $5 \mathbf{b}$ compound $5 f$ was obtained as yellowish liquid $(1.17 \mathrm{~g}, 81 \%)$

\subsection{General Method for Isourea Carboxylates 6a-f}

Starting from isothiourea carboxylates $\mathbf{5 a}-\mathbf{f}(3.0 \mathrm{mmol}), 10 \mathrm{~mL}$ of ethanol and $10 \mathrm{~mL}$ of water were added into a $100 \mathrm{~mL}$ round flask and the mixture was refluxed for $72 \mathrm{~h}$. For isothiourea $5 \mathbf{a}, \mathrm{DMF}$ was used instead of ethanol. The solvent was evaporated from the reaction mixture and the residue suspended in acetone, the suspension was cooled and filtered, the precipitate was washed with acetone and dried. In the hydrolysis of isothioureas $\mathbf{5 e , f}, \mathbf{f}$ the reaction mixture was filtered and the solvents were evaporated. $5 \mathrm{~mL}$ of acetone were added and $50 \mathrm{~mL}$ of $\mathrm{CHCl}_{3}$ were slowly added, the mixture was stirred until a beige solid precipitates, which was filtered and washed with $\mathrm{CHCl}_{3}$ to get $6 \mathbf{e}, \mathbf{f}$.

\subsubsection{Sodium (3-Benzothiazol-2-Y1-Isoureido)-Acetate $\mathbf{6 a}$}

$0.32 \mathrm{~g}, 40 \%$ yield; white powder; $\mathrm{mp}=210{ }^{\circ} \mathrm{C}(\mathrm{dc})$.

\subsubsection{Sodium 2-(3-Benzothiazol-2-Y1-Isoureido)-Propionate $6 \mathbf{b}$}

White powder; $0.6 \mathrm{~g}, 70 \%$ yield; $\mathrm{mp}=205^{\circ} \mathrm{C}(\mathrm{dc})$.

\subsubsection{Sodium (3-Benzothiazol-2-Yl-Isoureido)-Phenyl-Acetate 6c}

White powder; $0.75 \mathrm{~g}, 72 \%$ yield; $\mathrm{mp}=250{ }^{\circ} \mathrm{C}(\mathrm{dc})$.

\subsubsection{Sodium 2-(3-Benzothiazol-2-Yl-Isoureido)-3-Phenyl-Propionate 6d}

White powder; $0.81 \mathrm{~g}, 75 \%$ yield; $\mathrm{mp}=149-150{ }^{\circ} \mathrm{C}$.

\subsubsection{Sodium 2-(3-Benzothiazol-2-Yl-Isoureido)-3-Methyl-Butirate 6e}

White powder; $0.61 \mathrm{~g}, 65 \%$ yield $\mathrm{mp}=199-201^{\circ} \mathrm{C}$. 


\subsubsection{Sodium 2-(3-Benzothiazol-2-Y1-Isoureido)-4-Methyl-Pentanonate $6 f$}

White powder; $0.69 \mathrm{~g}, 70 \%$ yield; $\mathrm{mp}=201-203{ }^{\circ} \mathrm{C}$.

3.4. General Method for SMe-Isothiourea Carboxylate Methyl Esters 8a-f and $\mathbf{9 e , f}$ or Isourea Carboxylate Methyl Esters 10a-f and Urea Methyl Ester 12e,f

In a $100 \mathrm{~mL}$ round flask, $3.0 \mathrm{mmol}$ of the corresponding isothiourea carboxylate $5 \mathbf{a}-\mathbf{f}$ or urea carboxylate $\mathbf{6 a}-\mathbf{f}$ were dissolved in DMF $(10 \mathrm{~mL})$, methyl iodide $(3.5 \mathrm{mmol})$ were added and the mixture was stirred for $12 \mathrm{~h}$ on an ice bath and then $12 \mathrm{~h}$ at room temperature. At the end of the reaction, $50 \mathrm{~mL}$ of water were added and the corresponding ester was extracted with $\mathrm{CHCl}_{3}$. Chloroform was eliminated and the $O$-methyl compounds were purified by crystallization in ethanol. Compounds $9 \mathbf{e}$ or 9f were separated from $\mathbf{8 e}$ or $\mathbf{8 f}$ by crystallization from their ethanol mixture. Compounds $\mathbf{1 2 e}$ or $\mathbf{1 2 f}$ were separated from 10e or $\mathbf{1 0 f}$ using a chloroform/acetone 10:1 mixture in a silica gel chromatography column. 12e and $\mathbf{1 2 f}$ were precipitated from hexane.

\subsection{1. (E)-2-(3-Benzothiazol-2-Yl-2-Methyl-Isothioureido)-Acetic Acid Methyl Ester 8a}

White crystals; $0.73 \mathrm{~g}, 83 \%$ yield; $\mathrm{mp}=145-146{ }^{\circ} \mathrm{C}$.

3.4.2. (S,E)-(+)-2-(3-Benzothiazol-2-Y1-2-Methyl-Isothioureido)-Propionic Acid Methyl Ester 8b White crystals; $0.74 \mathrm{~g}, 80 \%$ yield; $\mathrm{mp}=100-101^{\circ} \mathrm{C}$.

3.4.3. (S,E)-(+)-2-(3-Benzothiazol-2-Yl-2-Methyl-Isothioureido)-Phenyl-Acetic Acid Methyl Ester 8c White crystals; $0.83 \mathrm{~g}, 75 \%$ yield; $\mathrm{mp}=133-134{ }^{\circ} \mathrm{C}$.

3.4.4. (S,E)-(-)-2-(3-Benzothiazol-2-Yl-2-Methyl-Isothioureido)-3-Phenyl-Propionic Acid Methyl Ester 8d

White crystals; $0.64 \mathrm{~g}, 56 \%$ yield; $\mathrm{mp}=84-85^{\circ} \mathrm{C}$.

3.4.5. (S,E)-(-)-2-(3-Benzothiazol-2-Y1-2-Methyl-Isothioureido)-3-Methyl-Butanoic Acid Methyl Ester 8e

Viscous liquid; $0.49 \mathrm{~g}$, 49\% yield.

3.4.6. (S,E)-(-)-2-(3-Benzothiazol-2-Y1-2-Methyl-Isothioureido)-4-Methyl-Pentanonic Acid Methyl Ester 8f

Viscous liquid; $0.53 \mathrm{~g}, 51 \%$ yield.

3.4.7. 3-Methyl-2-[2-Methyl-3-(3-Methyl-3H-Benzothiazol-2-Ylidene)-Isothioureido]-Butyric Acid Methyl Ester 9e

White crystals; $0.084 \mathrm{~g}, 8 \%$ yield; $\mathrm{mp}=163-164{ }^{\circ} \mathrm{C}$; MS: $\mathrm{M}+\mathrm{H}=352.1$ (79.1\%).

3.4.8. 4-Methyl-2-[2-Methyl-3-(3-Methyl-3H-Benzothiazol-2-Ylidene)-Isothioureido]-Pentanoic Acid Methyl Ester $9 f$

White crystals; $0.27 \mathrm{~g}$, $25 \%$ yield; $\mathrm{mp}=177-178^{\circ} \mathrm{C}$; MS: $\mathrm{M}+\mathrm{H}=366.0$ (80.1\%).

3.4.9. (3-Benzothiazol-2-Yl-Isoureido)-Acetic Acid Methyl Ester 10a

White powder; $0.65 \mathrm{~g}$, 82\% yield; $\mathrm{mp}=170-180^{\circ} \mathrm{C}$; MS: $\mathrm{M}+\mathrm{H}=266.06$ (85\%).

3.4.10. 2-(3-Benzothiazol-2-Yl-Isoureido)-Propionic Acid Methyl Ester 10b

White powder; $0.68 \mathrm{~g}, 86 \%$ yield; $\mathrm{mp}=149-150{ }^{\circ} \mathrm{C} ; \mathrm{MS}: \mathrm{M}+\mathrm{H}=280.07$ (85.6\%). 
3.4.11. (3-Benzothiazol-2-Y1-Isoureido)-Phenyl-Acetic Acid Methyl Ester 10c

White powder; $0.73 \mathrm{~g}, 72 \%$ yield; $\mathrm{mp}=112-114{ }^{\circ} \mathrm{C} ; \mathrm{MS}: \mathrm{M}+\mathrm{H}=342.1(83.1 \%)$.

3.4.12. 2-(3-Benzothiazol-2-Yl-Isoureido)-3-Phenyl-Propionic Acid Methyl Ester 10d White powder; $0.32 \mathrm{~g}, 30 \%$ yield, $70-71^{\circ} \mathrm{C}(\mathrm{mp}), \mathrm{MS}: \mathrm{M}+\mathrm{H}=356.1$ (80.6\%).

3.4.13. 2-(3-Benzothiazol-2-Yl-Isoureido)-3-Methyl-Butyric Acid Methyl Ester 10e

Viscous liquid; $0.6 \mathrm{~g}$, $66 \%$ yield; $\mathrm{MS}: \mathrm{M}+\mathrm{H}=308.1$ (82.7\%).

3.4.14. 2-(3-Benzothiazol-2-Y1-Isoureido)-4-Methyl-Pentanoic Acid Methyl Ester 10f Viscous liquid; $0.52 \mathrm{~g}, 54 \%$ yield; $\mathrm{MS}: \mathrm{M}+\mathrm{H}=321.0$ (84.1\%).

3.4.15. 3-Methyl-2-[3-(3-Methyl-3H-Benzothiazol-2-Ylidene)-Ureido]-Butyric Acid Methyl Ester 12e White powder; $0.23 \mathrm{~g}, 24 \%$ yield; $\mathrm{mp}=100-101^{\circ} \mathrm{C} ; \mathrm{MS}: \mathrm{M}+\mathrm{H}=322.1$ (83\%).

3.4.16. 4-Methyl-2-[3-(3-Methyl-3H-Benzothiazol-2-Ylidene)-Ureido]-Pentanoic Acid Methyl Ester 12f White powder; $0.21 \mathrm{~g}, 21 \%$ yield; $\mathrm{mp}=87-89^{\circ} \mathrm{C}$; $\mathrm{MS}: \mathrm{M}+\mathrm{H}=336.1(82 \%)$.

\subsection{General Method for Isourea Amides 11a-f or Urea-Amides $\mathbf{1 3 e , f}$}

In a $100 \mathrm{~mL}$ round flask, $3.00 \mathrm{mmol}$ of the corresponding isourea carboxylate methyl esters 10a-f or urea methyl esters 12e,f were dissolved in ethanol $(10 \mathrm{~mL})$, methyl amine $40 \%$ in water $(3.5 \mathrm{mmol})$ were added and the mixture was refluxed for $24 \mathrm{~h}$. At the end of the reaction, the precipitate was filtered and washed with plenty of acetone.

\subsubsection{2-[3-(3H-Benzothiazol-2-Ylidene)-Ureido]-N-Methyl-Acetamide 11a}

White powder; $0.63 \mathrm{~g}, 80 \%$ yield; $\mathrm{mp}=260-270{ }^{\circ} \mathrm{C}(\mathrm{dc}) ; \mathrm{MS}: \mathrm{M}+\mathrm{H}=265.1(82.1 \%)$.

\subsubsection{2-[3-(3H-Benzothiazol-2-Ylidene)-Ureido]-N-Methyl-Propionamide 11b}

White powder; $0.81 \mathrm{~g}, 97 \%$ yield; $\mathrm{mp}=250-260^{\circ} \mathrm{C}(\mathrm{dc}), \mathrm{MS}: \mathrm{M}+\mathrm{H}=279.09$ (84.8\%).

\subsubsection{2-[3-(3H-Benzothiazol-2-Ylidene)-Ureido]-N-Methyl-2-Phenyl-Acetamide 11c}

White powder; $0.98 \mathrm{~g}, 96 \%$ yield; $\mathrm{mp}=270-290{ }^{\circ} \mathrm{C}(\mathrm{dc}) ; \mathrm{MS}: \mathrm{M}+\mathrm{H}=341.1$ (77.9\%).

3.5.4. 2-[3-(3H-Benzothiazol-2-Ylidene)-Ureido]-N-Methyl-3-Phenyl-Propionamide 11d

White powder; $1.06 \mathrm{~g}, 93 \%$ yield, $\mathrm{mp}=270-280{ }^{\circ} \mathrm{C}(\mathrm{dc}) ; \mathrm{MS}: \mathrm{M}+\mathrm{H}=355.1$ (77.5\%).

\subsubsection{2-[3-(3H-Benzothiazol-2-Ylidene)-Ureido]-N-Methyl-3-Methyl-Butiramide 11e}

White powder; $0.55 \mathrm{~g}, 60 \%$ yield; $\mathrm{mp}=205-207^{\circ} \mathrm{C}(\mathrm{dc}), \mathrm{MS}: \mathrm{M}+\mathrm{H}=307.12(80.1 \%)$.

3.5.6. 2-[3-(3H-Benzothiazol-2-Ylidene)-Ureido]-N-Methyl-4-Methyl-Pentylamide 11f

White powder; $0.6 \mathrm{~g}, 63 \%$ yield; $\mathrm{mp}=138-140{ }^{\circ} \mathrm{C}$; $\mathrm{MS}: \mathrm{M}+\mathrm{H}=321.1$ (76.1\%).

3.5.7. 3,N-Dimethyl-2-[3-(3-Methyl-3H-Benzothiazol-2-Ylidene)-Ureido]-Butiramide 13e

White powder; $0.2 \mathrm{~g}, 20 \%$ yield; $\mathrm{mp}=205-206{ }^{\circ} \mathrm{C} ; \mathrm{MS}: \mathrm{M}+\mathrm{H}=321.1(79.1 \%)$.

3.5.8. 4-Methyl-2-[3-(3-Methyl-3H-Benzothiazol-2-Ylidene)-Ureido]-Pentanoic Acid Methylamide 13f

White powder; $0.46 \mathrm{~g}, 46 \%$ yield; $\mathrm{mp}=210-212{ }^{\circ} \mathrm{C}, \mathrm{MS}: \mathrm{M}+\mathrm{H}=335.1(79.9 \%)$. 


\section{Conclusions}

A six sodium salt series of isothiourea-carboxylate benzothiazoles $\mathbf{5 a}-\mathbf{f}$, as well as their methyl ester derivatives $\mathbf{8 a}-\mathbf{f}$, were obtained in moderate to good yields by the reaction of dimethylcarbonimidate benzothiazole 2 with sodium salts of glycine, (l)-alanine, (l)-phenylglycine, (l)-phenylalanine, (l)-valine, and (l)-leucine in stirring ethanol at room temperature and further methylation under mild conditions. The reaction is stereo selective, only the E-isomer was isolated, the X-ray structure of $(R, E)$-methyl-2-((benzothiazol-2-ylimino)(methyl-thio)methylamino)-2-phenylacetate 8c confirmed the stereochemistry of the reaction. The structures of $\mathbf{8 a}$ and $\mathbf{8 c}$ are stabilized by three center hydrogen bonding interactions $\mathrm{N} 3 \cdots \mathrm{H} 12 \cdots \mathrm{O} 14$ between the amino $\mathrm{N} 12 \mathrm{H} 12$ with the nitrogen atom of benzothiazole ring and the oxygen atom of the carbonyl group, forming two intramolecular adjacent $S(6)$ and $S(5)$ rings, respectively. This finding suggests the stereochemical assistance of the reaction by hydrogen bonding. When the same reactions were carried out in the presence of water, the urea-carboxylate benzotiazoles $\mathbf{6 a}-\mathbf{f}$ were obtained. Their further methylation produced the corresponding methyl esters $\mathbf{1 0 a}-\mathbf{f}$. In the methylation reaction of sodium isothiourea-carboxylates $\mathbf{5 e , f} \mathbf{f}$ and urea-carboxylates $\mathbf{6 e}, \mathbf{f}$, the corresponding N3Me methyl esters $\mathbf{9 e}, \mathbf{f}$ and $\mathbf{1 2 e}, \mathbf{f}$ were produced as byproducts, which were isolated. Methyl esters $\mathbf{8 a}-\mathbf{f}$ or $\mathbf{1 0 a}-\mathbf{f}$ and $\mathbf{9 e , f}$ or $\mathbf{1 2} \mathbf{e}, \mathbf{f}$ were used as starting materials to produce the corresponding urea carboximides $\mathbf{1 1 a}-\mathbf{f}$ and $\mathbf{1 3 e}, \mathbf{f}$ by the reaction with methyl amine. Further studies on the synthesis of chiral guanidines from SMe-isothioureas 8 are in progress.

Supplementary Materials: The following are available online. Table S1. Complementary data of SMe-isothiourea carboxylates $\mathbf{5 a}-\mathbf{f}$ and their methyl esters $\mathbf{8 a}-\mathbf{f}$. Table S2. X-ray crystal data of compounds $\mathbf{8 a}, \mathbf{8 b}, \mathbf{8 c}$ and $\mathbf{9 f}$. Table S3. ${ }^{1} \mathrm{H}$ NMR data of compounds $5 \mathbf{a}-\mathbf{f}\left(\mathrm{DMSO}-d_{6}\right)$. Table S4. ${ }^{13} \mathrm{CNMR}$ data of compounds $\mathbf{5 a}-\mathbf{f}\left(\mathrm{DMSO}-d_{6}\right)$. Table S5. ${ }^{1} \mathrm{H}$ NMR data of compounds $\mathbf{6 a}-\mathbf{f}\left(\mathrm{DMSO}-d_{6}\right)$. Table S6. ${ }^{13} \mathrm{CNMR}$ data of compounds $\mathbf{6 a}-\mathbf{f}\left(\mathrm{DMSO}-d_{6}\right)$. Table S7. ${ }^{1} \mathrm{HNMR}$ data of compounds $8 \mathbf{a}-\mathbf{d}\left(\mathrm{CDCl}_{3}\right)$. Table S8. ${ }^{13} \mathrm{C}$ NMR data of compounds $8 \mathbf{a}-\mathbf{d}\left(\mathrm{CDCl}_{3}\right)$. Table S9. ${ }^{1} \mathrm{H}$ NMR data of compounds $\mathbf{1 0 a}-\mathbf{f}\left(\mathrm{CDCl}_{3}\right)$. Table S10. ${ }^{13} \mathrm{CNMR}$ data of compounds $\mathbf{1 0 a}-\mathbf{f}\left(\mathrm{CDCl}_{3}\right)$. Table S11. ${ }^{1} \mathrm{H}$ NMR data of compounds 11a-f $\left(\mathrm{CDCl}_{3}\right)$. Table S12. ${ }^{13} \mathrm{C}$ NMR data of compounds $\mathbf{1 1 a}-\mathbf{f}\left(\mathrm{CDCl}_{3}\right)$.

Author Contributions: Reseach, A.C. and J.M.G.-E.; original draft preparation, writing-review and editing, A.C. and I.I.P.-M.; X-ray diffraction data curation, E.V.G.-B. and Á.A.R.-O.

Funding: This research received no external funding.

Acknowledgments: A. Cruz thanks Secretaría de Investigación y Posgrado del IPN (SIP-IPN) for financial support, Grants 20180754 and 20196686 and COTEBAL-IPN as well as CONACYT, México for the sabbatical study financial support (2018-2019).

Conflicts of Interest: The authors declare no conflict of interest.

\section{References}

1. Borthwick, A.D.; Davies, D.E.; Ertl, P.F.; Exall, A.M.; Haley, T.M.; Hart, G.J.; Jackson, D.L.; Parry, N.R.; Patikis, A.; Trivedi, N.; et al. Design and synthesis of pyrrolidine-5,5'-trans-lactams (5-oxo-hexahydropyrrolo $[3,2-b]$ pyrroles) as novel mechanism-based inhibitors of human cytomegalovirus protease. 4. Antiviral activity and plasma stability. J. Med. Chem. 2003, 46, 4428-4449. [CrossRef] [PubMed]

2. Akhtar, T.; Hameed, S.; Al-Masoudi, N.A.; Loddo, R.; La Colla, P. In vitro antitumor and antiviral activities of new benzothiazoles and 1,3,4-oxadiazole-2-tione derivatives. Acta Pharm. 2008, 58, 135-149. [CrossRef] [PubMed]

3. Ke, S.; Wei, Y.; Ziwen, Y.; Wang, K.; Liang, Y.; Shi, L. Novel cycloalkylthiophene-imine derivatives bearing benzothiazole scaffold: Synthesis, characterization and antiviral activity evaluation. Bioorg. Med. Chem. Lett. 2013, 23, 5131-5134. [CrossRef] [PubMed]

4. Haydon, D.J.; Stokes, N.R.; Ure, R.; Galbraith, G.; Bennett, J.M.; Brown, D.R.; Baker, P.J.; Barynin, V.V.; Rice, D.W.; Sedelnikova, S.E.; et al. An inhibitor of FtsZ with potent and selective anti-staphylococcal activity. Science 2008, 321, 1673-1675. [CrossRef] [PubMed]

5. Saeed, A.; Rafique, H.; Hameed, A.; Rasheed, S. Synthesis and antibacterial activity of some new 1-aroyl-3-(substituted-2-benzothiazolyl)thio-ureas. Pharm. Chem. J. 2008, 42, 191-195. 
6. Haydon, D.J.; Bennett, J.M.; Brown, D.; Collins, I.; Galbraith, G.; Lancett, P.; Macdonald, R.; Stokes, N.R.; Pramod, K.; Chauhan, J.K.S.; et al. Creating an antibacterial with in vivo efficacy: Synthesis and characterization of potent inhibitors of the bacterial cell division protein FtsZ with improved pharmaceutical properties. J. Med. Chem. 2010, 53, 3927-3936. [CrossRef] [PubMed]

7. Scheich, C.; Puetter, V.; Schade, M. Novel small molecule inhibitors of MDR mycobacterium tuberculosis by NMR fragment screening of antigen 85C. J. Med. Chem. 2010, 53, 8362-8367. [CrossRef] [PubMed]

8. Singh, M.K.; Tilak, R.; Nath, G.; Awasthi, S.K.; Agarwal, A. Design, synthesis and antimicrobial activity of novel benzothiazole analogs. Eur. J. Med. Chem. 2013, 63, 635-644. [CrossRef]

9. Singh, M.; Gangwar, M.; Nath, G.; Singh, S.K. Synthesis, DNA cleavage and antimicrobial activity of 4-thiazolidinones-benzothiazole conjugates. Indian J. Exp. Biol. 2014, 52, 1062-1070.

10. Mittal, S.; Samota, M.K.; Kaur, J.; Seth, G.; Mittal, S.; Samota, M.K.; Kaur, J.; Seth, G. Synthesis, spectral, and antifungal evaluation of phosphorylated and thiophosphorylated benzothiazole derivatives. Phosphorus Sulfur 2007, 182, 2105-2113. [CrossRef]

11. Huang, W.; Yang, G.-F. Microwave-assisted, one-pot syntheses and fungicidal activity of polyfluorinated 2-benzylthiobenzothiazoles. Bioorg. Med. Chem. 2006, 14, 8280-8285. [CrossRef] [PubMed]

12. Yevich, J.P.; Temple, D.L.; Covington, R.R.; Owens, D.A.; Seidehamel, R.J.; Dungan, K.W. Antiallergics: 3-(1H-Tetrazol-5-yl)-4H-pyrimido[2,1-b ]benzo-thiazol-4-ones. J. Med. Chem. 1982, 25, 864-868. [CrossRef] [PubMed]

13. Musser, J.H.; Brown, R.E.; Love, B.; Baily, K.; Jones, H.; Kahen, R. Synthesis of 2-(2,3-dihydro-2-oxo-1,3,4oxadiazol-5-yl) benzo heterocycles. A novel series of orally active antiallergic agents. J. Med. Chem. 1984, 27, 121-125. [CrossRef] [PubMed]

14. Ager, I.R.; Barnes, A.C.; Danswan, G.W.; Hairsine, P.W.; Kay, D.P.; Kennewell, P.D.; Matharu, S.S.; Miller, P.; Robson, P. Synthesis and oral antiallergic activity of carboxylic acids derived from imidazo[2,1-c] [1,4]benzoxazines, imidazo[1,2-a]quinolines, imidazo[1,2-a]quinoxalines, imidazo[1,2-a]quinoxalinones, pyrrolo[1,2-a]quinoxalinones, pyrrolo[2,3-a]quinoxalinones, and imidazo[2,1-b]benzothiazoles. J. Med. Chem. 1988, 31, 1098-1115. [PubMed]

15. Pattan, S.R.; Suresh, C.; Pujar, V.D.; Reddy, V.V.K.; Rasal, V.P.; Kotti, B.C. Synthesis and antidiabetic activity of 2-amino [5'(4-sulphonylbenzylidine)-2,4-thiazolidinedione]-7-chloro-6-fluorobenzothiazole. Indian J. Chem. 2005, 44, 2404-2408.

16. Moreno-Díaz, H.; Villalobos-Molina, R.; Ortiz-Andrade, R.; Díaz-Coutiño, D.; Medina-Franco, J.L.; Webster, S.P.; Binnie, M.; Estrada-Soto, S.; Ibarra-Barajas, M.; León-Rivera, I.; et al. Antidiabetic activity of N-(6-substituted-1,3- benzothiazol-2-yl)benzenesulfonamides. Bioorg. Med. Chem. Lett. 2008, 18, 2871-2877. [CrossRef] [PubMed]

17. Mariappan, G.; Prabhat, P.; Sutharson, L.; Banerjee, J.; Patangia, U.; Nath, S. Synthesis and antidiabetic evaluation of benzothiazole derivatives. J. Korean Chem. Soc. 2012, 56, 251-256. [CrossRef]

18. Yan, Y.; Xie, X.; Zhu, N.; Liu, G. Benzothiazoles exhibit broad-spectrum antitumor activity: Their potency structure-activity and structure-metabolism relationships. Eur. J. Med. Chem. 2014, 76, 67-78.

19. Gabr, M.T.; El-Gohary, N.S.; El-Bendary, E.R.; El-Kerdawy, M.M. Synthesis and in vitro antitumor activity of new series of benzothiazole and pyrimido[2,1-b]benzothiazole derivatives. Eur. J. Med. Chem. 2014, 85, 576-592. [CrossRef]

20. Gabr, M.T.; El-Gohary, N.S.; El-Bendary, E.R. El-Kerdawy, M.M. New series of benzothiazole and pyrimido[2,1-b]benzothiazole derivatives: Synthesis, antitumor activity, EGFR tyrosine kinase inhibitory activity and molecular modeling studies. Med. Chem. Res. 2015, 24, 860-878. [CrossRef]

21. Yurttas, L.; Tay, F.; Demirayak, S. Synthesis and antitumor activity evaluation of new 2-(4-aminophenyl)benzothiazole derivatives bearing different heterocyclic ring. J. Enzyme Inhib. Med. Chem. 2015, 30, 458-465. [PubMed]

22. Paramashivappa, R.; Kumar, P.P.; Rao, S.P.V.; Rao, S. Design, synthesis and biological evaluation of benzimidazole/benzothiazole and benzoxazole derivatives as cyclooxygenase inhibitors. Bioorg. Med. Chem. Lett. 2003, 13, 657-660. [PubMed]

23. Deshmukh1, V.K.; Raviprasad, P.; Kulkarni, P.A.; Kuberkar, S.V. Design, synthesis and biological activities of novel 4H-pyrimido [2, 1-b] [1,3] benzothiazole derivatives. Int. J. Chem. Tech. Res. 2011, 3, 136-142.

24. Munirajasekhar, D.; Himaja, M.; Sunil, V.M. Synthesis and anthelmintic activity of 2-amino-6-substituted benzothiazoles. Int. Res. J. Pharm. 2011, 2, 114-117. 
25. Suresh, C.H.; Rao, J.V.; Jayaveera, K.N.; Subudhi, S.K. Synthesis and anthelmintic activity of 3-(2hydrazinobenzothiazoles)-substituted indole-2-one. Int. Res. J. Pharm. 2011, 2, 257-261.

26. Balaji, P.N.; Ranganayakulu, D.; Yadav, K.R.; Jayamma, J.; Kumar, S.; Sivaramaiah, C. Anthelmintic and anti-microbial activities of synthesized heterocyclic pyrazole and its derivatives from fluoro substituted hydrazino benzothiazole. Int. J. Pharm. Tech. Res. 2014, 6, 1970-1975.

27. Reddy, D.R.S.; Raparla, L.P.; Pradeep, K.; Ahmed, S.M.; Sindhura, J. Synthesis, analytical characterization, antimicrobial, anti-oxidant and anti-convulsant evaluation of some novel 6-fluorobenzothiazole substituted pyrazole analogues. Int. J. Pharm. Chem. 2013, 3, 72-81.

28. Joseph, J.; Janaki, G.B. Synthesis, structural characterization and biological studies of copper complexes with 2-aminobenzothiazole derivatives. J. Mater. Environ. Sci. 2014, 5, 693-704. [CrossRef]

29. Fen, R.; Christian, S. Antioxidant potential of novel 2-(4-amino-2-arylaminothiazol-5-oyl) benzothiazoles. Int. J. Pharm. Bio. Sci. 2014, 5, 74-79.

30. Yadav, A.G.; Patil, V.N.; Asrondkar, A.L.; Naik, A.A.; Ansulkar, P.V.; Bobade, A.S.; Chowdhary, A.S. Anti-oxidant and anti-microbial activities of pyrazolyl-benzothiazole derivatives using Vilsmeier-Haack reaction. Rayazan J. Chem. 2012, 5, 117-120.

31. Nessim, M.I.; Ahmed, M.H.M.; Ali, A.M.B.; Salem, A.A.; Attia, S.K. The effect of some benzothiazole derivatives as antioxidants for base stock. Int. J. Curr. Res. 2013, 5, 111-1113.

32. Choudhary, S.; Kini, S.G.; Mubeen, M. Antioxidant activity of novel coumarin substituted benzothiazole derivatives. Der. Pharm. Chem. 2013, 5, 213-222.

33. Raju, G.N.; Karumudi, B.S.; Rao, N.R. Benzothiazole-Versatile heterocyclic nucleus in medicinal chemistry: A review. Int. J. Pharm. Chem. 2015, 5, 104-114.

34. Keri, R.S.; Patil, M.R.; Patil, S.A.; Budagumpi, S. A comprehensive review in current developments of benzothiazole based molecules in medicinal chemistry. Eur. J. Med. Chem. 2015, 89, 207-251. [CrossRef] [PubMed]

35. Coles, M.P. Bicyclic-guanidines, -guanidinates and -guanidinium salts: Wide ranging applications from a simple family of molecules. Chem. Commun. 2009, 3659-3676.

36. Ishikawa, T. Superbases for Organic Synthesis: Guanidines, Amidines, Phosphazenes and Related Organocatalysts; Johon Wiley and Sons Ltd.: Chippenham, UK, 2009.

37. Berlinck, R.G.S.; Burtoloso, A.C.B.; Trindade-Silva, A.E.; Romminger, S.; Morais, R.P.; Bandeira, K.; Mizuno, C.M. The chemistry and biology of organic guanidine derivatives. Nat. Prod. Rep. 2010, 27, 1871-1907. [PubMed]

38. Fu, X.; Tan, C.-H. Mechanistic considerations of guanidine-catalyzed reactions. Chem. Commun. 2011, 47, 8210-8222.

39. Cunha, S.; Rodriguez, M.T., Jr. The first bismuth(III)-catalyzed guanylation of thioureas. Tetrahedron Lett. 2006, 47, 6955-6956.

40. Liu, F.; Lu, G.-Y.; He, W.-J.; Hu, J.; Mei, Y.-H.; Zhu, L.-G. Synthesis of calix[4]arene derivatives with alkyl guanidinium or chiral bicyclic guanidinium. Synthesis 2001, 607-611.

41. Gers, T.; Kunce, D.; Markowski, P.; Izdebski, J. Reagents for efficient conversion of amines to protected guanidines. Synthesis 2004, 37-42.

42. Ibatullin, F.M.; Selivanov, S.I.; Shavva, A.G. A General procedure for conversion of s-glycosyl isothiourea derivatives into thioglycosides, thiooligosaccharides and glycosyl thioesters. Synthesis 2001, 419-422. [CrossRef]

43. Porcheddu, A.; Giacomelli, G.; Chinghine, A.; Masala, S. New cellulose-supported reagent: A sustainable approach to guanidines. Org. Lett. 2004, 6, 4925-4927. [CrossRef] [PubMed]

44. Garvey, E.P.; Oplinger, J.A.; Tanoury, G.J.; Sherman, P.A.; Fowler, M.; Marshall, S.; Harmon, M.F.; Paith, J.E.; Furfine, E.S. Potent and selective inhibition of human nitric oxide synthases. Inhibition by non-amino acid isothioureas. J. Biol. Chem. 1994, 269, 26669-26676. [PubMed]

45. Di Giacomo, C.; Sorrenti, V.; Salerno, L.; Cardile, V.; Guerrera, F.; Siracusa, M.A.; Avitabile, M.; Vanella, A. Novel inhibitors of neuronal nitric oxide synthase. Exp. Biol. Med. 2003, 228, 486-490.

46. Harusawaa, S.; Sawada, K.; Magata, T.; Yoneyama, H.; Araki, L.; Usami, Y.; Hatano, K.; Yamamoto, K.; Yamamoto, D.; Yamatodani, A. Synthesis and evaluation of N-alkyl-S-[3-(piperidin-1-yl)propyl]isothioureas: High affinity and human/rat species-selective histamine $\mathrm{H} 3$ receptor antagonists. Bioorg. Med. Chem. Lett. 2013, 23, 6415-6420. [CrossRef] [PubMed] 
47. Paesano, N.; Marzocco, S.; Vicidomini, C.; Carmela, S.; Autore, G.; De Martino, G.; Sbardella, G. Synthesis and biological evaluation of 3-benzyl-1-methyl- and 1-methyl-3-phenyl-isothioureas as potential inhibitors of iNOS. Bioorg. Med. Chem. Lett. 2005, 15, 539-543. [PubMed]

48. Cruz, A.; Padilla-Martínez, I.I.; García-Báez, E. A synthetic method to access symmetric and non-symmetric 2-(N,N'-disubstituted)guanidinebenzothiazoles. Molecules 2012, 17, 10178-10191.

49. Cruz, A.; Padilla-Martínez, I.I.; García-Báez, E.V.; Juárez, J.M. S-Methyl-(-N-aryl and-N-alkyl) isothioureas derived from 2-aminobenzothiazole. Arkivoc 2008, 200, 209.

50. Sheldrick, G.M. A short history of SHELX. Acta Cryst. 2008, 64, 112-122.

51. Farrugia, L.J. WinGX suite for small-molecule single-crystal crystallography. J. Appl. Crystallogr. 1999, 32, 837-838. [CrossRef]

52. Macrae, C.F.; Edgington, P.R.; McCabe, P.; Pidcock, E.; Shields, G.P.; Taylor, R.; Towler, M.; van de Streek, J. Mercury: Visualization and analysis of crystal structures. J. Appl. Crystallogr. 2006, 39, 453-457. [CrossRef]

53. Spek, A.L. Single-crystal structure validation with the program PLATON. J. Appl. Crystallogr. 2003, 36, 7-13. [CrossRef]

Sample Availability: Samples of the compounds are available from the authors.

(C) 2019 by the authors. Licensee MDPI, Basel, Switzerland. This article is an open access article distributed under the terms and conditions of the Creative Commons Attribution (CC BY) license (http://creativecommons.org/licenses/by/4.0/). 